\title{
BIOCHEMICAL AND HISTOPATHOLOGICAL CHANGES IN ALBINO RATS AFTER LONG TERM CONSUMPTION OF SOME HEATED OILS
}

\author{
$B Y$
Essam M. Ali; Adel A. Zalata*; Fatma A. Kamel ; Nadia E. Atwan**; Sohayla M. EL-sherbiny \\ Departments of Forensic Medicine and Clinical Toxicology, Biochemistry* and Puthology**. \\ Faculty of Medicine, Mansoura University, Egypi
}

\begin{abstract}
This study was carried out on 70 adult male albino rats with average weight $102.57 \pm 14.39 \mathrm{gram} .1$ pilot survey study anong 1200 females in Mansoura Faculty of Medicine was done to choove the oils to be lested. These oils were used once for frying potatoes chips for different periods $(1 / 4,1 / 2$, und 1 hour $)$. repeatedly used 2, 3 and 4 times; each $1 / 4$ hour and repeatedly used 2 times; each $1 / 2$ hour. The effect of heating on oils was determined by assessment of Thio Barbituric Acid Reactive Substances (TBARS) in the fiesh and hented studied oils. Results revented that the deteriorative effect of heat increases by incretrsing the duration of oil usc and the repctition of heating was much more destructive than the continumis use of the oil. Oils heated repeatedly for 4 times; each $1 / 4$ hour was found to have the maximum TBARS content and so they were chosen for the preparation of diet used during the study on experimental animals. The animals were randomly divided inio seven groups: 10 rats each and fed for three months the prepared experimental diet. First group of animals was fed oil free diet (negative control group). Animals was fed diet containing fresh (non-heated) sunflower (FS) oil in the second group (positive control group), repeutedly heated sunflower (HS) oil in the third group, fresh (non-hented) cottonsecd (FC) oil in the fourh group (positive control group, repeatedly heated cottonseed $(\mathrm{HC})$ oil in the fifth group. fresh (non-hented) mixed (sunflower and cotfonseed) (FM) oil in the sixth group (positive control group) (and icpentedly heated mixed (sunfower and cottonseed) (HM) oil in the seventh group. Rats were sacrificed and dissected at the end of third month of the study. Organs (liver, kidney, colon, heart, and testis) were immediately excised and prepared for pathological studies and blood samples were çollected for biochemical studies including estimation of "TBARS" and glutathione peroxidase in serum, separation of $\alpha-\delta$ - tocopherols and tocopherol acetate and estimation of serum ALT, AST, albumin, creatinine and urea. In experimental animals it was found that chronic consumption of any of the repeatedly heated studied oils increases the serum level of the peroxidative products (TBARS), decreases the antioxidant defense of the body (seram glutathione peroxidnse and tocopherols) and compromising the liver and kidney functions presented as increase in the serum hepatic enzymes, decrease in serum albunin and increase in both
\end{abstract}


serum creatinine and urea. Pathological changes were found in liver, kidney, colon, and testes of animals fed repeasedly heased oils. These effects were more pronounced in animals fed repeatedly heated cottonseed oil followed by the repeatedly heated mised oil then the repeatedly heated sunflower oil.

\section{INTRODUCTION}

The role of dietary fat and oils in human nutrition is one of the important areas of concern and investigation in the field of nutritional science. The findings of these investigations have wide ranging implications for consumers, health care providers and nutrition educators, as well as food producers, processors and distributors. New evidence concerning the benefits and risks associated with particular aspects of dietary fat is constantly emerging in both the scientific literatures and the popular media. At times, controversies about these findings evolve (F.A.O., 1994). Fats and oils are heated at high temperatures during baking, grilling and frying; however, deep fat frying is the most common method of high temperature treatment. Deep fat frying is a popular food preparation method produces the desirable fried food flavour, golden brown colour and crisp texture. Because of the great consumption of frying oils and fats, the effects of high temperature on oils and fats is of major concern both for product quality and nutrition (Warner, 1999).

Deep fat frying is an important, ubiquitous and highly versatile process, which has been used since antiquity to cook a wide spectrum of products. Its unique contribution to sensory characteristics, together with the relatively low cost of large-scale frying, has made fried foods the staples of the ever growing late 20th century fast food industry (Saguy and Dana, 2003).

The use of oil remains one of the must popular methods for the preparation of foods. This is particularly true in Egypt and the majority of the Arab world where fallafel (a deep fried vegetable patty) forms the staple food item in the diet and is widely available at street level from vendors (Tewfik et al., 1998).

The purpose of the present work is to study the effect of heating on oils and the effect of chronic consumption of repcatcdly heated oils on experimental animals.

\section{MATERIAL AND METHODS}

The most commonly used oils (sunflower, cottonseed, and mixed oils) determined by a pilot study were chosen for the study. These oils were purchased from supermarket and were used one time in frying potatoes chips in aluminum wok for different periods $(1 / 4,1 / 2$, and 1 hour $)$, repeatedly used 2, 3 and 4 times; each $1 / 4$ 
hour and repeatedly used 2 times; each $1 /$ 2 hour. Repeated heating of oils was done without any topping up (without replenishing the oil in the fryer with fresh oil) under conditions corresponding to the normal household frying practices (domestic frying). The effect of heating on oils was predicted by estimation of the content of the TBARS in fresh and heated studied oils according to the method described by Draper et al. (1993).

The study was carried out on 70 adult male albino rats with average weight $102.57 \pm 14.39$ gram obtained from animal house of Mansoura Faculty of Medicine. The rats were, housed in metallic cages at room temperature with day and right light rhythm. After a week of acclimatization to the housing conditions, rats were randomly divided into seven groups; 10 rats each and fed the prepared experimental diet.

Diets were prepared as a $15 \%(\mathrm{~W} / \mathrm{W})$ mixture of the test oil (sunflower, cottonseed or mixed) fresh or heated (repeatedly heated for 4 times; each $1 / 4$ hour have the maximum TBARS content) and the rodent chew.

This study used the oil concentration as $15 \%$ in the diet because the fat content of the potatoes when fried as chips increases to 7-15 gram fat per 100 gram potatoes (Fox and Cameron, 1995).

\section{Classification of animals;}

Rats were classified into 7 groups. First group of animals was fed oil free diet (negative control group). Animals were fed diet containing fresh (non- heated) sunflower (FS) oil in the second group (positive control group), repeatedly heated (4 times; $1 / 4$ hour each) sunflower (HS) oil in the third group, fresh (non- heated) cottonseed (FC) oil in the fourth group (positive control group, repeatedly heated (4 times; $1 / 4$ hour each) cottonseed (HC) oil in the fifth group, fresh (non-heated) mixed (sunflower and cottonseed) (FM) oil in the sixth group (positive control group) and repeatedly heated (4 times; 1 / 4 hour each) mixed (sunflower and cottonseed) (HM) oil in the seventh group.

Rats were kept on diet for three months. Rats were sacrificed and dissected at the end of third month of the study. Organs (liver, kidney, colon, heart, and testis) were immediately excised and prepared for pathological studies according to the method of Stevens (1982).

\section{Biochemical studies :}

Blood samples were collected for biochemical studies as heparinized blood samples prepared by using $0.3 \mathrm{ml}$ heparin on $2 \mathrm{ml} \mathrm{blood} \mathrm{(heparin} \mathrm{"5000} \mathrm{IU"} \mathrm{of} \mathrm{Nile}$ Co. Batch No. 90071) and Serum (blood samples were centrifuged at 3500 Round Per Minute (RPM) for 5 minutes on Sigma 2- 15 centrifuge). Samples were kept in re- 
frigerator until the time of biochemical studies.

Effect on lipid peroxidation was determined by estimation of "TBARS" in serum according to method described by Draper et al. (1993).

Effect on antioxidants was determined by estimation of serum glutathione peroxidase (Paglia and Valentine, 1967).

Furthermore, Separation of $\alpha-, \delta$ - tocopherols using tocopherol acetate as an internal standard was done by high performance liquid chromatography (H.PLC) using Philips PU 4100 liquid chromatography sysitem wilh $20 \mu$ l samplè injector loop. The detector used was a Unicam PU 4225 UV with variable wave length detection and adjusted at UV $292 \mathrm{rm}$. The mobile phase was $100 \%$ methanol at a flow rate equilibrated at $0.7 \mathrm{ml} / \mathrm{min}$. The column used for the chromatographic separation was reversed phase Spherisorb ODS1 column. Serum was mixed with tocopherol acetate and extracted with n-hexan using an electric shaker for 5 minutes then the mixture was centrifuged to separate the hexan layer. The extract was completely dried at $40 \circ \mathrm{C}$ and reconstituted with $300 \mu l$ of methanol (Liu et al., 2000).

Effect on liver functions was determined by estimation of serum albumin (Doumas et al., 1971); Serum aspartate aminotrasferase (AST) and Serum alanine aminotrasferase (ALT) according to the method described by Reitman and Frankel (1957).

Effect on kidney functions was determined by estimation of both serum urea and creatinine concentration according to the methods described by Sampson et al. (1980) and Heinegard and Tiderstrom (1973), respectively.

\section{Statistical analysis :}

Statistical analysis was done by using the Statistical Package for Social Science (SPSS) program version 10, 1999. The following statistical parameters were utilized arithmetic mean $(x)$, standard deviation (SD) , Student t-test and correlation coefficient. Significance was considered when $p$ value less than 0.05 .

\section{RESULTS}

\section{Effects of heating on oils :}

Results of this study showed that there was an increase in the TBARS content of the studied heated oils which was more rising on increasing the duration of heating. It was found that the TBARS content of sunflower, cottonseed and mixed oils increased significantly in different durations of heating in comparison to the fresh oil (Table 1).

Moreover, the repetition of heating was 
much more destructive than the continuous use of the oil (e.g., TBARS content of oils used for one hour frying session was less TBARS content of oils used for two sessions; each $1 / 2$ hour and was much less than TBARS content of oils used for four sessions; each $1 / 4$ hour). TBARS content was found to be increased in heated cottonseed oil more than heated mixed oil and heated sunflower oil (Figure 1).

II. Effects of chronic consumption of repeatedly heated ffour times; each $1 / 4$ hour (H4/4)\} oils |sunflower, cottonseed, mixed on experimental animals:

Serum TBARS was found to be significantly increased ( $p<0.001$ ) in animals fed any of the studied heated oils in comparison to both the negative and the positive control groups while, there was insignificant increase in its value in the positive control groups (animals fed fresh oils) in comparison to the negative control group (animals fed oil free diet) (Table 2).

In comparison to animals in negative control group, serum glutathione peroxidase was insignificantly decreased in animals fed fresh oils while significantly decreased in those fed repeatedly heated sunflower oil ( $p \leq 0.01$ ) and in animals fed repeatedly heated cottonseed or mixed oil ( $p \leq 0.001$ ). In comparison to animals of positive and negative control group, serum glutathione was insignificantly de- creased in animals fed repeatedly heated sunflower or mixed oil while, significantly decreased in those fed repeatedly heated cottonseed oil (p $\leq 0.001$ ) (Table 3).

Both $\alpha$ - and $\delta$ - tocopherols showed insignificant difference between positive and negative control groups ( $p>0.05$ ) and significant decrease in animals fed repeatedly heated oils in comparison to negative and positive control groups. $\delta$ - tocopherol decreased in animals fed repeatedly heated cottonseed or mixed oils ( $p<0.001$ ) more than in animals fed repeatedly heated sunflower oil ( $p<0.01$ ) (Figures 2, 3, 4 and 5) and (Table 4).

Results of the present study showed positive correlation between the TBARS content of the oil, either fresh or heated, and the serum levels of TBARS (Figure 10). In addition a negative correlation was showed between the serum concentration of TBARS and that of glutathione peroxidase (Figure 11), $\alpha$ - tocopherol (Figure 12) and $\delta$ - tocopherol (Figure 13). Whereas glutathione peroxidase was positively correlated with $\alpha$ - tocopherol (Figure 14), and $\delta$ - tocopherol (Figure 15).

The present results showed that animals fed heated studied oils have a significantly higher levels ( $p<0.001$ ) of serum ALT and AST in comparison to both negative and positive control groups. Serum albumin concentration insignificantly in- 
creased in animals fed any of the fresh studied oils but it decreased significantly in animals fed heated studied oils specially heated cottonseed oil (Table 5).

Serum creatinine and urea concentration showed insignificant difference between positive and negative control groups $(p>0.05)$ while they were significantly increased in animals fed heated studied oils when compared to both negative and positive control groups (Table 6).

Pathological changes were found in liver, kidney, colon, and testes of animals fed heated oils whereas, the heart did not show any pathologic effects. Maximum pathological effects were found in animals fed repeatedly heated cottonseed oil then animals fed repeatedly heated mixed oil while those fed repeatedly heated sunflower oil had the least pathological changes. These results were correlated with the biochemical changes associated with the chronic use of the heated studied oils.

Lesions in the liver were vaculation of hepatocytes with areas of lymphocytic infiltration and necrosis (Figure 6 ).

The renal pathology appeared in the form of glomerular and interstitial lymphocytic infiltrate with cloudy swelling which occurred nearly in all animals fed heated oils. In addition, tubular casts ap- peared in those fed repeatedly heated cottonseed or mixed oil and renal tubular necrosis which occurred in one animal only of those fed repeatedly heated cottonseed oil (Figure 7 ).

Erosion of the colonic mucosa occurred in animals fed repeatedly heated cottonseed oil while those fed repeatedly heated mixed oil had mucosal hyperplasia. Degenerative mucosal changes appeared in both groups. Chronic colitis was found in all animals but was maximally and presented as follicular colitis in animals fed repeatedly heated cottonseed oil with haemosidrin inside the macrophages indicating recurrent bleeding (Figure 8 ).

Testicular pathology presented as hypospermatogenesis with degenerated spermatogonia and accumulation of spermatid debris in animals fed repeatedly heated cottonseed or mixed oil ( Figure 9 ).

\section{DISCUSSION}

Because of concern about the types of changes that take place in fats during oxidative and thermal deterioration, many chemical and biological studies have been carried out (Alexander, 1981). The use of oil remains one of the most popular methods for the preparation of foods. This is particularly true in Egypt and the majority of the Arab world where fallafel (a deep fried vegetable patty) forms the staple 
food item in the diet and is widely available at street level from vendors (Tewfik et al., 1998).

The increased TBARS content of the studied heated oils in this study which was more rising on increasing the duration of heating coincide with observations in other studies on heated sunflower oil (Eder and Stangl, 2000) and heated cottonseed oil (El - Mehallawi et al.,2000).

The increased level of TBARS in oils following repetition of heating more than continuous heating in the present work is in agreement with Andrikopoulos et al. (2002). This may be explained by that at a high temperature (during continuous heating) the water is lost more quickly producing a steam blanket over the frying kettle and protect the fat against atmospheric oxygen (Alexander, 1981). FAO (1994) stated that the continuous use provides a protective water vapour blanket that protects against oxidation.

Results of the present work revealed that the cottonseed oil was exposed to the deteriorative effect of heating more than the mixed oil and the sunflower oil, as in the study of Abdel -Khalek and Abdel Rahman (1996). The lower TBARS contents found in sunflower oil than in cottonseed oil is in contrast with the fact that sunflower oil contains more polyunsaturated fatty acids (Gutebrie et al., 1995).
This agree with the concept that fat high in monoenes may be considerably more toxic than more highly unsaturated fats when heated under the same conditions (Alexander, 1981) and support the opinion that fatty acid unsaturation of dietary oils is not the only determining factor of the antioxidant capacity. Therefore, the optimal balance between the content of unsaturated fatty acids and natural antioxidants in dietary oils appear to be of major importance (Scaccini et al., 1992). Moreover, recent work suggest that the benefits occurred by lowering polyunsaturated falty acids could be lost if the levels of anlioxidants such as tocopherols are reduced (BOtha et al., 2003).

The significantly increased serum TBARS in animals fed heated studied oils, is in harmony with Liu and Huang (1995). Increased serum TBARS may be due to absorption of TBARS from the heated oil in the gastrointestinal tract or due to peroxidation of plasma lipids (Sheehy et al., 1994). The results of present study showed positive correlation between the TBARS content of the oil, either fresh or heated, and the serum levels of TBARS in accordance with the findings of Nwanguma et al. (1999).

In our study, the significant decrease in serum glutathione peroxidase in animals fed heated studied oils coincide with Narasimhamurthy and Raina (1999). In fact, 
glutathione peroxidase enzyme activity is influenced by severa! factors like heating and frying conditions, nature of fat, extent of peroxidation, presence of antioxidants, duration of feeding and the degree of unsaturation of the diet (Maraschiello et al., 1999).

In addition, the study showed significant decrease in both $\alpha$ - and $\delta$ - tocopherols by feeding heated studied oils in comparison to negative and positive control groups in agreement with findings of Liu and Huang (1995). The reduced levels of $\alpha$ - tocopherol could be due to the distruction of $\alpha$-tocopherol in the gastrointestinal tract by free radicals present in the heated oil. Another possibility could be that $\alpha$-tocopherol in plasma is oxidized by peroxyl radicals or lipid hydroperoxides absorbed from the diet. Diet supplementation with $\alpha$ - tocopherol acetate reduced tissue susceptibility to lipid peroxidation with varying degrees depending on the tissue (Sheehy et al., 1994).

The significant negative correlation between the serum TBARS and that of glutathione peroxidase, $\alpha$ - tocopherol and $\delta$ tocopherol, and the positive correlation of glutathione peroxidase with $\alpha$ - tocopherol, and $\delta$; tocopherol are in harmony with Eder and Stangl (2000), and Liu et al. (2000).These results are expected as the lipid peroxidation is a suitable index to evaluate vitamin E requirements. On the other hand, Maraschiello et al. (1999) observed a negative relationship between glutathione peroxidase activity and tissue

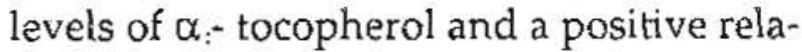
tionship was evidenced between TBARS and the antioxidant enzyme activity. The biochemical mechanism of interaction between glutathione peroxidase and vitamin $E$ has remained a fascirating question. Although selenium could prevent some, but not all, of the symptoms of vitamin $\mathrm{E}$ deficiency, vitamin E do not replace glutathione peroxidase in protecting from acure peroxidative stress (Cheng et al., 1999).

The higher levels of serum ALT, AST , creatinine and urea as well as lower serum albumin concentration in the present study is in contrast to the study of Eder and Stangl (2000) which revealed no effect of thermoxidized sunflower oil, on plasma biochemical variables (ALT, AST, albumin, creatinine, and urea) but their experiment period was shorter than that of the present work. The lower serum albumin in this study can be explained by the fact that; almost all amino acids react with primary and secondary products of oxidized lipids, thereby decreasing the digestive utilization of protein, amino acids (Neilsen et al., 1985).

Histopathological examination of albino rat organs in this study revealed that animals fed heated studied oils had pathological changes in liver, kidney, colon, and 
testes whereas, the heart did not show any pathologic effects. Maximum pathological effects were found in animals fed repeatedly heated cottonseed oil then animals fed repeatedly heated.mixed oil while those fed repeatedly heated sunflower oil had the least pathological changes. These results were correlated with the biochemical changes associated with the chronic use of the heated studied oils.

The pathological lesions in the liver and kidney coincide with those found in the study of Alexander (1987). Burk et al. (1995) concluded that depletion of glutathione in the liver and kidney leads to necrosis in these organs associated with evidence of lipid peroxidation.

The enhancement of cell proliferation induced by heated polyunsaturated oil may be caused by non specific tissue injury and the irritating effects of free fatty acids and their oxidation products (Bruce, 1987).This may explain mucosal hyperplasia occurred in animals fed repeatedly heated mixed oil in the present study.

The pathological changes in testes may be attributed to the rapid and continuous cell turnover in testicles, which render them sensitive to stimuli such as chemical agents arising from thermally oxidized fats. Dysfunctional Sertoli cells may be causative factor of decreased primary and secondary spermatogonia, because these cells function to organize the germinal epithelium and regulate the cyclic production of sperm in the tubules. Injury of stem cells may also be an etiological factor as these cells are responsible for somniferous tubules renewal (Alexander, 1987). Hypospermatogenic effect of long term consumption of repeatedly heated oils may be explained by a change in spermatozoa membrane fluidity, which is a major consequence of lipid peroxidation. Change in fatty acid composition of phospholipids of sperm membrane by reactive oxygen species may be another cause of hypospermatogenesis (Zalata et al., 1998).

\section{CONCLUSION \& RECOMMENDATIONS}

In conclusion deteriorative effect of heat on dietary oils increases by increasing the duration of oil use and the repetition of heating is much more destructive than the continuous use of the oil .In addition chronic consumption of any of the repeatedly heated studied oils increases the serum level of the peroxidative products (TBARS), decreases the antioxidant defense of the body and compromising the liver and kidney functions in experimental animals. These effects were more pronounced in animals fed repeatedly heated cottonseed oil followed by the repeatedly heated mixed oil then the repeatedly heated sunflower oil. According to the results of this study it is recommended that fry- 
ing should be avoided as much as possible and be replaced by other methods of cooking and frying oil must not be overheated and must be changed frequently. In addition it is better to use sunflower oil in fry- ing as it showed better tolerance to effect of heating than mixed and cottonseed oil. Human risks can be modulated by reduction of fried food consumption or food fortification with synthetic antioxidants. 
Table ( 1 ): Comparison of TBARS content ( $\mathrm{nmol} / \mathrm{ml}$ ) in the fresh and repeatedly heated sunflower, cotton seed and mixed oils.

\begin{tabular}{|c|c|c|c|c|c|c|c|c|c|c|}
\hline & & & Fresh & $\begin{array}{l}\text { H } 1 / \overline{4} \\
\text { (once) }\end{array}$ & $\begin{array}{l}\text { H } 2 / 4 \\
\text { (twice) }\end{array}$ & $\begin{array}{c}\text { H } 3 / 4 \\
\text { (three times) }\end{array}$ & $\begin{array}{c}\text { II } 4 / 4 \\
\text { (four times) }\end{array}$ & $\begin{array}{l}\text { H } 1 / 2 \\
\text { (once) }\end{array}$ & $\begin{array}{c}\text { H } 2 / 2 \\
\text { (twice) }\end{array}$ & $\begin{array}{c}\text { HI } 1 \\
\text { (once) }\end{array}$ \\
\hline \multirow{3}{*}{ 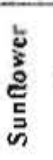 } & \multirow{3}{*}{ 훙 } & $\begin{array}{l}\text { Meait } \\
\pm \mathrm{SD} \\
\end{array}$ & $\begin{aligned} & 1.15 \\
&+ 0.029 \\
&\end{aligned}$ & $\begin{array}{r}1.54 \\
\pm 0.15 \\
\end{array}$ & $\begin{array}{r}5.72 \\
+0.088 \\
\end{array}$ & $\begin{array}{r}7.15 \\
+0.038 \\
\end{array}$ & $\begin{array}{r}9.06 \\
+0.059 \\
\end{array}$ & $\begin{aligned} & 2.92 \\
&+ 0.075 \\
&\end{aligned}$ & $\begin{array}{r}6.92 \\
+0.106 \\
\end{array}$ & $\begin{array}{r}4.07 \\
+0.007 \\
\end{array}$ \\
\hline & & $\mathbf{T}$ & & $4 . \overline{78}$ & 8.12 & 10.1 & 20.1 & 5.1 & 9.5 & 7.1 \\
\hline & & $\mathbf{P}$ & & $0.017^{4}$ & $<0.001^{\circ}$ & $<0.001^{* * *}$ & $<0.001^{\bullet \bullet \bullet}$ & $<0.001 *$ & $<0.001^{* * *}$ & $<0.001^{\cdots}$ \\
\hline \multirow{3}{*}{ 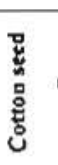 } & \multirow{3}{*}{5} & $\begin{array}{l}\text { Mean } \\
\pm \mathrm{SD} \\
\end{array}$ & $\begin{aligned} & 5.53 \\
&+ 0.023 \\
&\end{aligned}$ & $\begin{array}{c}6.31 \\
+0.14 \\
\end{array}$ & $\begin{array}{r}9.45 \\
+0.92 \\
\end{array}$ & $\begin{array}{r}12.72 \\
\pm 0.15 \\
\end{array}$ & $\begin{array}{r}16.66 \\
+1.69 \\
\end{array}$ & $\begin{array}{l}9.57 \\
+0.18 \\
\end{array}$ & $\begin{aligned} & 12.08 \\
&+ 0.068 \\
&\end{aligned}$ & $\begin{array}{l}10.47 \\
+0.004 \\
\end{array}$ \\
\hline & & $T$ & & 5.22 & 8.95 & 10.23 & 12.19 & 8.1 & 10.1 & 9.1 \\
\hline & & $\mathbf{P}$ & & $0.014^{\circ}$ & $<0.00\}^{\star \bullet 4}$ & $<0.001^{\circ+\infty}$ & $<0.001 \cdots$ & $<0.001 \cdots$ & $<0.001^{\cdots *}$ & $<0.001^{* 4}$ \\
\hline \multirow{3}{*}{ 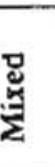 } & \multirow{3}{*}{$\approx$} & $\begin{array}{l}\text { Mean } \\
\pm \mathrm{SD}\end{array}$ & $\begin{array}{r}1.5 \\
\pm 0.13 \\
\end{array}$ & $\begin{array}{r}5.62 \\
\pm 0.23 \\
\end{array}$ & $\begin{array}{r}7.54 \\
\pm \quad 0.16\end{array}$ & $\begin{array}{r}11.45 \\
\pm 0.51\end{array}$ & $\begin{array}{r}11.72 \\
\pm 0.86\end{array}$ & $\begin{aligned} & 5.98 \\
\pm & 0.026\end{aligned}$ & $\begin{array}{r}7.55 \\
\pm 0.27\end{array}$ & $\begin{array}{r}6.95 \\
\pm 0.003 \\
\end{array}$ \\
\hline & & $r$ & & 9.1 & 11.1 & 13.1 & 13.5 & 9.3 & 11.17 & 10.1 \\
\hline & & $\mathrm{P}$ & & $<0.001^{* \infty}$ & $<0.001 * *$ & $<0.001^{\bullet \bullet \bullet}$ & $<0.001^{+4<}$ & $<0.001^{\bullet \bullet \bullet}$ & $<0.001^{+\bullet}$ & $<0.001^{\circ}$ \\
\hline
\end{tabular}

Insignilicant when $\mathrm{p}>0.05$.

( ). Slgnificant when $\mathrm{p} \leq 0.05$.

(“) Highly significant when $p \leq 0.01$.

( ${ }^{\circ . *)}$ Very highly significant when $p \leq 0.001$

Table ( 2 ) The statistical comparison of the serum TBARS concentration ( $\mathrm{nmol} / \mathrm{ml}$ ) in animals after chronic consumption of the fresh or repeatedly heated studied oils.

\begin{tabular}{|c|c|c|c|c|c|c|c|}
\hline & Contral & FS & HS & $\mathbf{F C}$ & HC & FM & HM \\
\hline $\begin{array}{l}\text { Meau } \\
\pm \text { SD }\end{array}$ & $\begin{array}{r}3.45 \\
\pm 0.85 \\
\end{array}$ & $\begin{array}{c}3.73 \\
\pm \quad 0.78 \\
\end{array}$ & $\begin{array}{r}6.39 \\
+\quad 0.89 \\
\end{array}$ & $\begin{array}{r}4.49 \\
+\quad 1.03 \\
\end{array}$ & $\begin{array}{r}10.33 \\
\pm 2.22 \\
\end{array}$ & $\begin{array}{c}4.33 \\
\pm 0.67 \\
\end{array}$ & $\begin{array}{r}9.02 \\
\pm \quad 0.97 \\
\end{array}$ \\
\hline$T_{1}$ & & 0.76 & 6.82 & 1.93 & 10.1 & 1.94 & .13 .51 \\
\hline$P_{1}$ & & 0.45 & $<0.001^{\circ 00}$ & 0.054 & $<0.001^{\circ}$ & 0.053 & $<0.001^{\circ}$ \\
\hline $\mathrm{T}_{2}$ & & \multicolumn{2}{|c|}{7.11} & \multicolumn{2}{|c|}{7.53} & \multicolumn{2}{|c|}{12.54} \\
\hline$\underline{P_{2}}$ & & \multicolumn{2}{|c|}{$<0.00\}^{\circ 00}$} & \multicolumn{2}{|c|}{$<0 . \overline{001}^{\circ .5}$} & \multicolumn{2}{|c|}{$<0.001^{200}$} \\
\hline
\end{tabular}

Insignificant when $\mathrm{p}>0.05$.

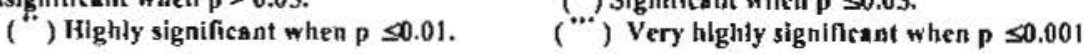

Table ( 3 ) :The statistical comparison of the serum glutathione peroxidase concentration (U/L) in animals after chronic consumption of the fresh or repeatedly heated studied oils.

\begin{tabular}{|c|c|c|c|c|c|c|c|}
\hline & Control & FS & HS & FC & $\mathrm{HC}$ & FM & $H M$ \\
\hline $\begin{array}{l}\text { Mean } \\
+\mathrm{SD} \\
\end{array}$ & $\begin{array}{r}1418.7 \\
+\quad 208.42 \\
\end{array}$ & $\begin{array}{r}1281.6 \\
+\quad 288.46 \\
\end{array}$ & $\begin{array}{r}1132.7 \\
+\quad 213.05 \\
\end{array}$ & $\begin{array}{r}1147.8 \\
+\quad 218.67 \\
\end{array}$ & $\begin{array}{c}575.4 \\
\pm 136.88\end{array}$ & $\begin{array}{r}1191 \\
+\quad 191.96\end{array}$ & $\begin{array}{r}1041 . \overline{7} \\
+\quad 202.22\end{array}$ \\
\hline$T_{1}$ & & 1.43 & 3.58 & 1.79 & 10.1 & 1.71 & 4.9 \\
\hline $\mathbf{P}_{1}$ & & 0.16 & $0.002^{\circ}$ & 0.09 & $<0.001^{\circ}$ & 0.1 & $<0.001^{\circ "}$ \\
\hline$T_{2}$ & & \multicolumn{2}{|c|}{1.55} & \multicolumn{2}{|c|}{5.91} & \multicolumn{2}{|c|}{1.71} \\
\hline $\mathbf{P}_{2}$ & & \multicolumn{2}{|c|}{0.13} & \multicolumn{2}{|c|}{$<0.001^{\prime \prime \prime}$} & \multicolumn{2}{|c|}{0.105} \\
\hline
\end{tabular}

Insignificant when $\mathrm{p}>0.05$.

(.). Significant when $\mathrm{p} \leq 0.05$.

(“) Highly signiflcant when $\mathrm{p} \leq 0.01$. (.) Very highly significaut when $p \leq 0.001$ 
Table (4): The statistical comparison of both serum $\alpha$-tocopherol and serum $\delta$-tocopherol concentration $(\mathrm{Ug} / \mathrm{ml})$ in animals after chronic consumption of the fresh or repeatedly heated studied oils.

\begin{tabular}{|c|c|c|c|c|c|c|c|c|}
\hline & & Control & FS & HS & $\mathrm{FC}$ & $\mathrm{HC}$ & FMI & $\mathrm{HMI}$ \\
\hline \multirow{5}{*}{ 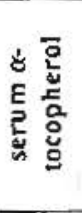 } & $\begin{array}{l}\text { Mean } \\
+S D \\
\end{array}$ & $\begin{array}{l}21.43 \\
+\quad 2.7 \\
\end{array}$ & $\begin{array}{r}20.74 \\
+\quad 2.45 \\
\end{array}$ & $\begin{array}{r}15.27 \\
+\quad 1.93 \\
\end{array}$ & $\begin{array}{r}18.95 \\
+\quad 2.42 \\
\end{array}$ & $\begin{array}{l}9.01 \\
+\quad 2.2 . \\
\end{array}$ & $\begin{array}{l}19.3 \\
+\quad 2.4 \\
\end{array}$ & $\begin{array}{l}10.96 \\
+\quad 2.13 \\
\end{array}$ \\
\hline & $T_{1}$ & & 0.68 & 5.7 & 2.03 & 9.24 & 1.99 & 12.06 \\
\hline & $P_{1}$ & & 0.51 & $<0.001^{\mathrm{rm}}$ & 0.07 & $<0.001^{\prime \prime}$ & 0.08 & $<0.001^{710}$ \\
\hline & $\mathrm{T}_{2}$ & & \multicolumn{2}{|c|}{10.22} & \multicolumn{2}{|c|}{10.02} & \multicolumn{2}{|c|}{6.86} \\
\hline & $P_{2}$ & & \multicolumn{2}{|c|}{$<0.001^{m}$} & \multicolumn{2}{|c|}{$<0.001^{\prime \prime \prime}$} & \multicolumn{2}{|c|}{$<0.001^{m+}$} \\
\hline \multirow{5}{*}{ 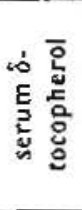 } & $\begin{array}{l}\text { Mean } \\
+S D \\
\end{array}$ & $\begin{array}{r}5.79 \\
+\quad 1.38 \\
\end{array}$ & $\begin{array}{r}5.65 \\
+\quad 1.56 \\
\end{array}$ & $\begin{array}{r}3.87 \\
+\quad 0.99 \\
\end{array}$ & $\begin{array}{r}4.39 \\
+\quad 0.77 \\
\end{array}$ & $\begin{array}{r}1.46 \\
+0.67 \\
\end{array}$ & $\begin{array}{r}4.96 \\
+\quad 0.99 \\
\end{array}$ & $\begin{array}{r}2.42 \\
+0.68 \\
\end{array}$ \\
\hline & $T_{1}$ & & 0.21 & 3.58 & 1.63 & 8.12 & 1.95 & 0.93 \\
\hline & $P_{1}$ & & 0.83 & $0.002^{17}$ & 0.117 & $<0.001^{\circ}$ & 0.052 & $<0.001^{\circ 00}$ \\
\hline & $T_{2}$ & & \multicolumn{2}{|c|}{3.97} & \multicolumn{2}{|c|}{6.91} & \multicolumn{2}{|c|}{5.04} \\
\hline & $\mathbf{P}_{2}$ & & \multicolumn{2}{|c|}{$<0.001^{\circ}$} & \multicolumn{2}{|c|}{$<0.001^{\circ}$} & \multicolumn{2}{|c|}{$<0.001^{\mathrm{m}}$} \\
\hline
\end{tabular}

Insignincant when $p>0.05$.
(") Highly slgnificant when $p \leq 0.03$.

( ) Signlicant when $p \leq 0.05$.

('). Very highly sigstificant when $p \leq 0.001$

Table ( 5 ): The statistical comparison of serum ALT (U/L), serum AST (U/L) and serum albumin (gm/di) in animals after chronic consumption of the fresh or repeatedly heated studied oils.

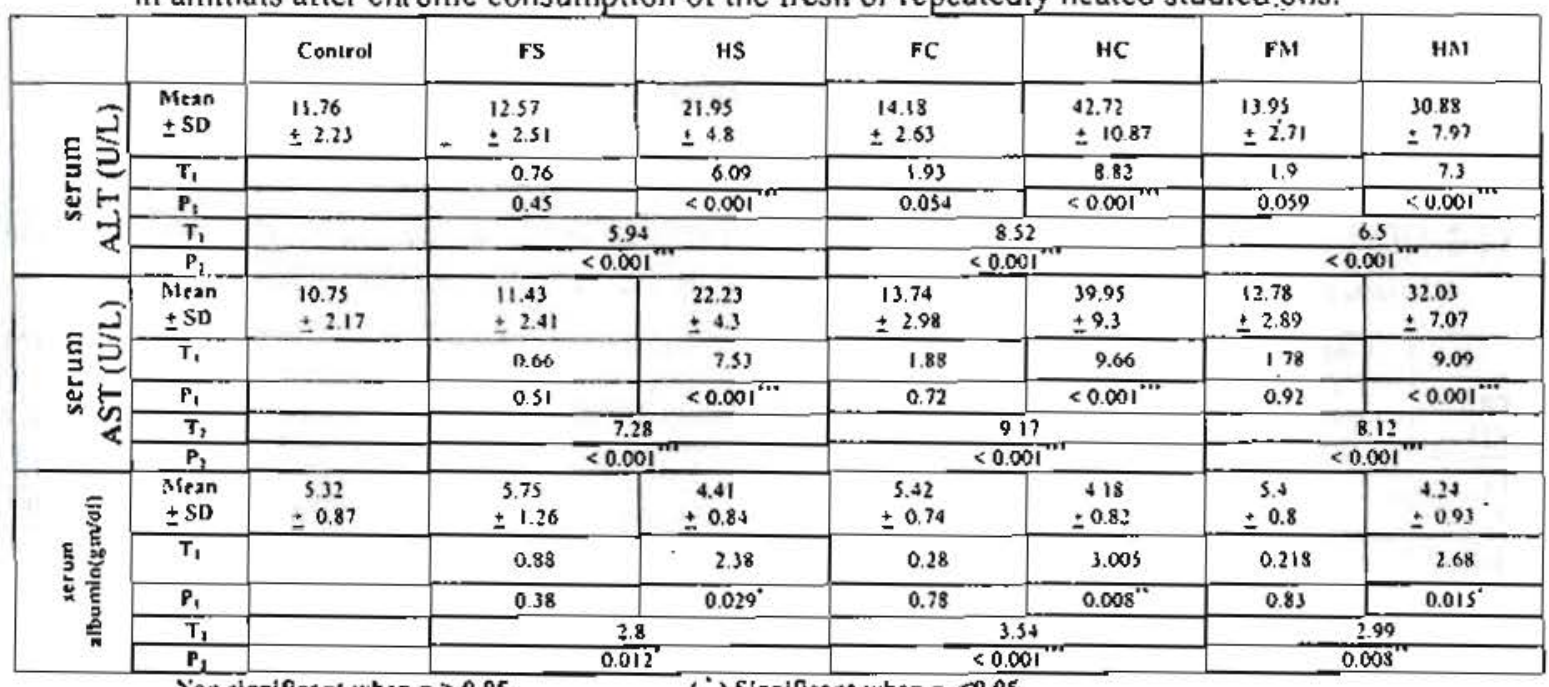

Nion significant when $p>0.05$. (ignificant when $\mathrm{g} \leq 0.05$.

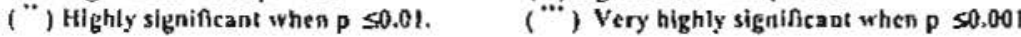

Table ( 6 ) : The statistical comparison of both serum creatinine concentration and senim urea concentration (mg/dl)) in animals after choronic consumption of the fresh or repeatedly heated studied oils.

\begin{tabular}{|c|c|c|c|c|c|c|c|c|}
\hline & & Controt & FS & IIS & FC & $\mathrm{HC}$ & FAI & HIM \\
\hline \multirow{5}{*}{ E } & $\begin{array}{l}\text { Mean } \\
+ \text { SD } \\
\end{array}$ & $\begin{array}{l}0.49 \\
0.07\end{array}$ & $\begin{array}{r}0.53 \\
+\quad 0.13 \\
\end{array}$ & $\begin{array}{r}0.66 \\
+\quad 0.1 \\
\end{array}$ & $\begin{array}{r}0.67 \\
+\quad 0.15 \\
\end{array}$ & $\begin{aligned} & 1.22 \\
&+ 0.29 \\
&\end{aligned}$ & $\begin{array}{l}0.57 \\
+0.09 \\
\end{array}$ & $\begin{array}{r}0.98 \\
+\quad 0.21 \\
\end{array}$ \\
\hline & $T_{1}$ & & 0.94 & 4.6 & 1.74 & 7.74 & 1.63 & 7.05 \\
\hline & $P_{1}$ & & 0.35 & $<0.001^{\mathrm{m}}$ & 0.098 & $<0.001^{m}$ & $0.1 \overline{17}$ & $<0.001^{20}$ \\
\hline & $r_{1}$ & & \multicolumn{2}{|c|}{2.22} & \multicolumn{2}{|c|}{5.34} & \multicolumn{2}{|c|}{6.7} \\
\hline & $\mathrm{P}_{2}$ & & \multicolumn{2}{|c|}{$0.039^{\circ}$} & \multicolumn{2}{|c|}{$<0.001^{m}$} & \multicolumn{2}{|c|}{$<\left.0.00\right|^{\circ}$} \\
\hline \multirow{5}{*}{ 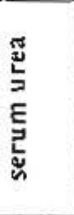 } & $\begin{array}{l}\text { Mean } \\
+S D \\
\end{array}$ & $\begin{array}{r}12.24 \\
+\quad 1.69 \\
\end{array}$ & $\begin{array}{r}13.36 \\
+\quad 3.31 \\
\end{array}$ & $\begin{array}{r}17.28 \\
+\quad 3.4 \\
\end{array}$ & $\begin{array}{r}14.67 \\
+\quad 3.8 \\
\end{array}$ & $\begin{array}{r}30.52 \\
+7.26 \\
\end{array}$ & $\begin{array}{r}13.49 \\
+\quad 2.2 \\
\end{array}$ & $\begin{array}{r}24.56 \\
+\quad 5.25 \\
\end{array}$ \\
\hline & $T_{1}$ & & 0.95 & 3.03 & 1.71 & 9.75 & 1.42 & 7.06 \\
\hline & $\mathbf{P}_{1}$ & & 0.35 & $0.007^{20}$ & 0.099 & $<0.001^{\prime \prime \prime}$ & 0.17 & $<0.001^{\mathrm{m}}$ \\
\hline & $\mathrm{T}_{2}$ & & \multicolumn{2}{|c|}{2.95} & \multicolumn{2}{|c|}{4.34} & \multicolumn{2}{|c|}{5.7} \\
\hline & $\mathbf{P}_{2}$ & & \multicolumn{2}{|c|}{$0.008^{\circ}$} & \multicolumn{2}{|c|}{$<0.001^{\circ 00}$} & \multicolumn{2}{|c|}{$<0.00 !^{\prime \prime \prime}$} \\
\hline
\end{tabular}

Insignificant $n$ when $p>0.05$. (i) Significant when $p \leq 0.05$

(") Highly signiflcant when $p \leq 0.01$. ("), Very hlghly signticant when $p \leq 0.001$

Mansoura J. Forensic Med. Ctin. Toxicol.

Vol. XII No.1, January 2005 
Ali et al ...

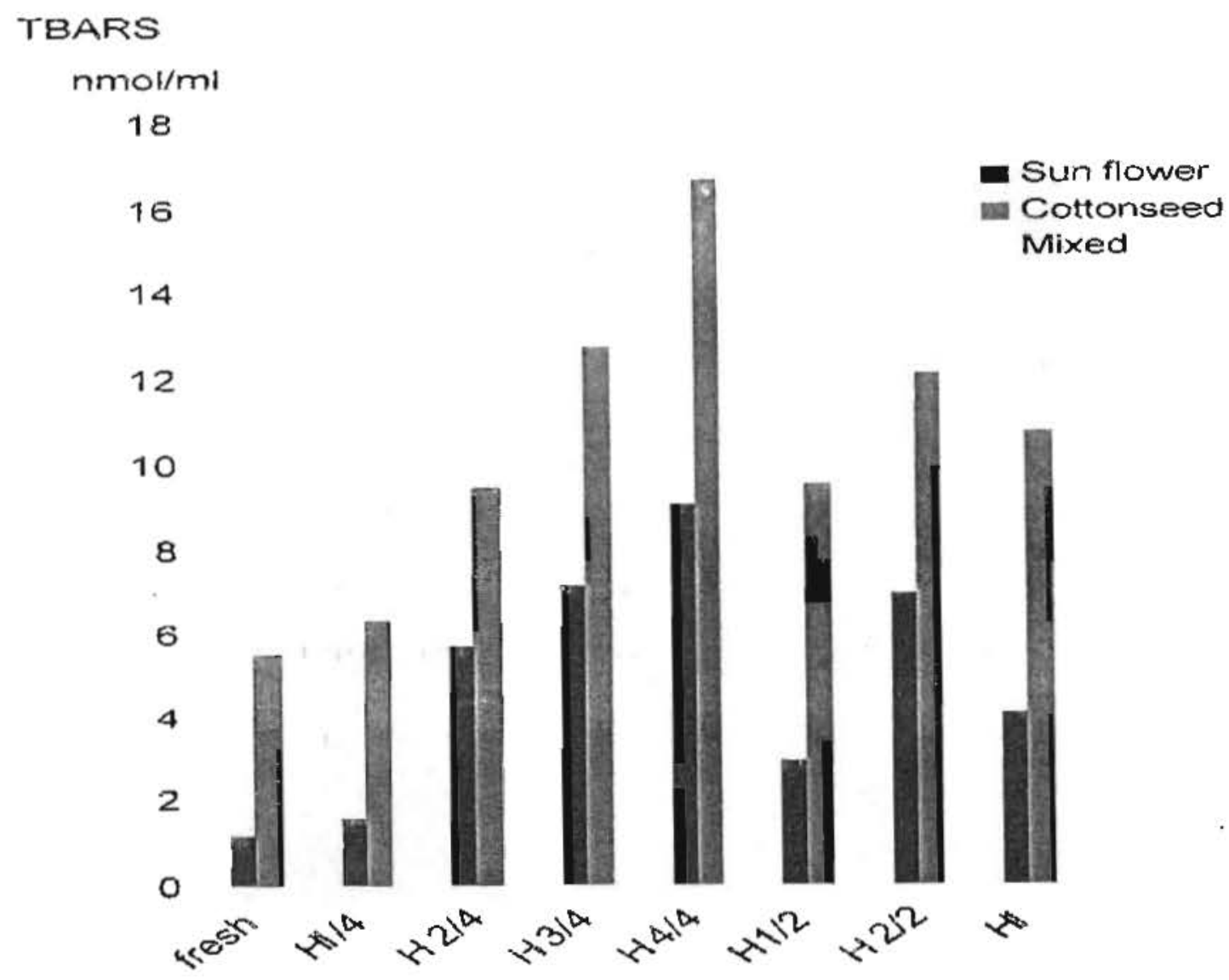

Fig. (1): Comparison of TBARS content in fresh and repeatedly heated sunflower, cottonseed, and mixed oils. 


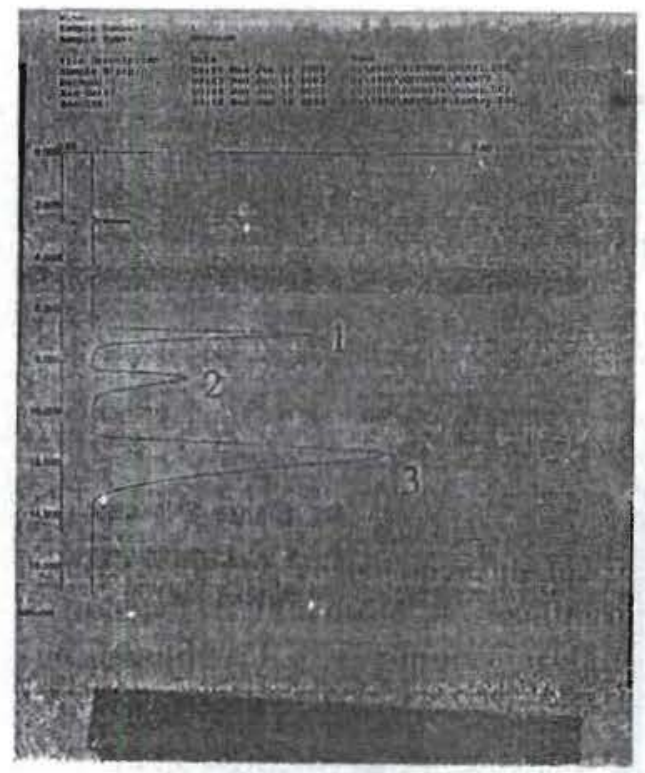

Fig. (2) : HPLC chromatograph for tocopherol standards. (1. $\delta$ tocopherol, 2. $\alpha$-tocopherol, 3. Tocopherolacetate).

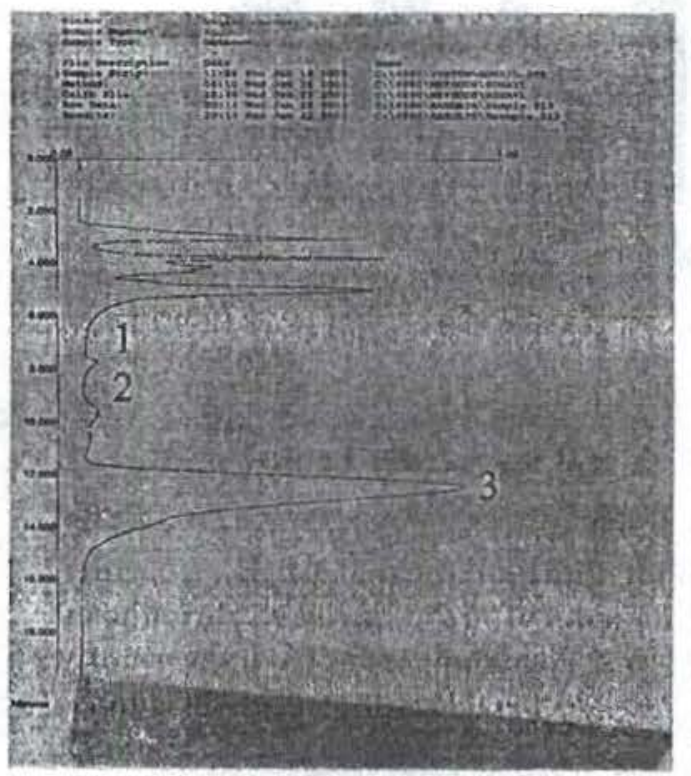

Fig. (4) : HPLC chromatograph for Tocopherols in serum of rat fed heated cottonseed oil. ( 1 . $\delta$ tocopherol, 2. $\alpha$-tocopherol, 3. Tocopherolacetate).

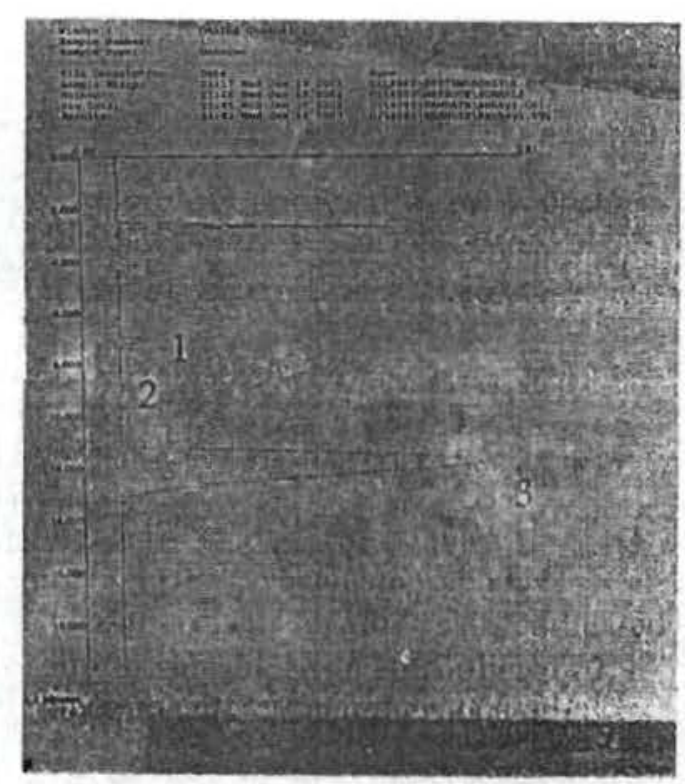

Fig. (3) : HPLC chromatograph for tocopherols in serum of rat fed heited sunflower oil. ( $1 . \delta$-tocopherol , 2. $\alpha$ - locopherol, 3. Tocopherolacelite).

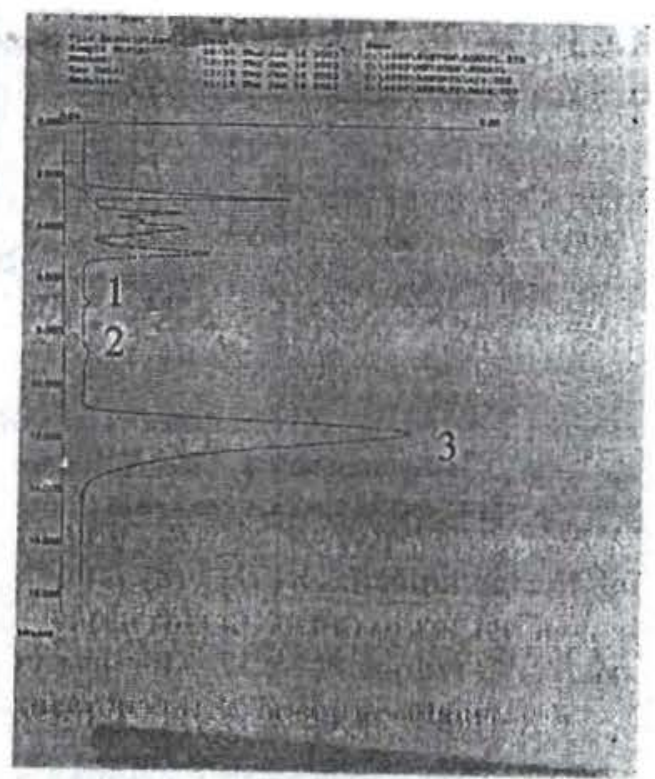

Fig. (5) : HPLC chromatograph for tocopherols in serum of rat fed heated mixed oil. ( $1 . \delta$-tocopherol, 2 . $\alpha$ - tocopherol, 3. Tocopherolacetate). 


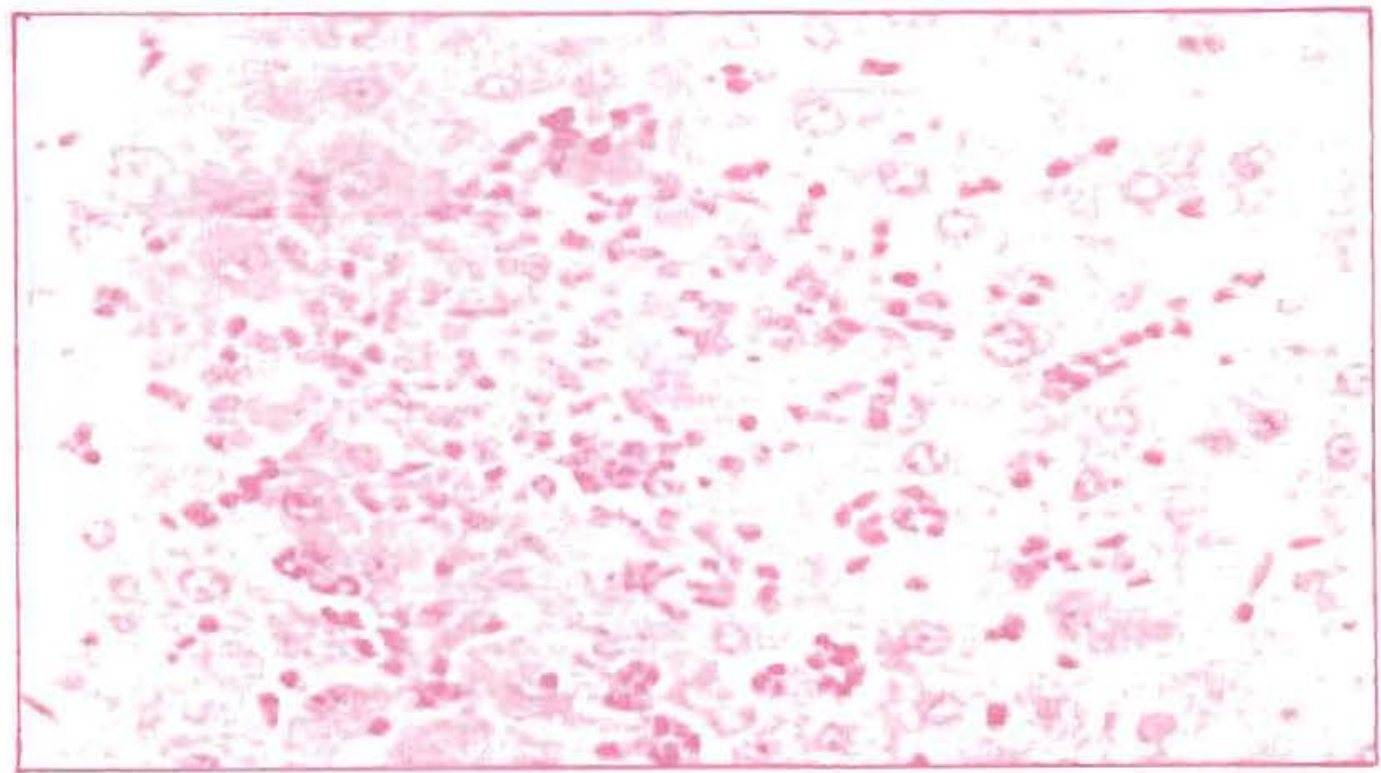

Fig. (6) : Section in liver of rats fed repeatedly heated cottonseed oil. it shows mild vaculation and focal confluent necrosis with apoptotic bodies. ( $\mathrm{H} \times \& \mathrm{E} \times 100)$.

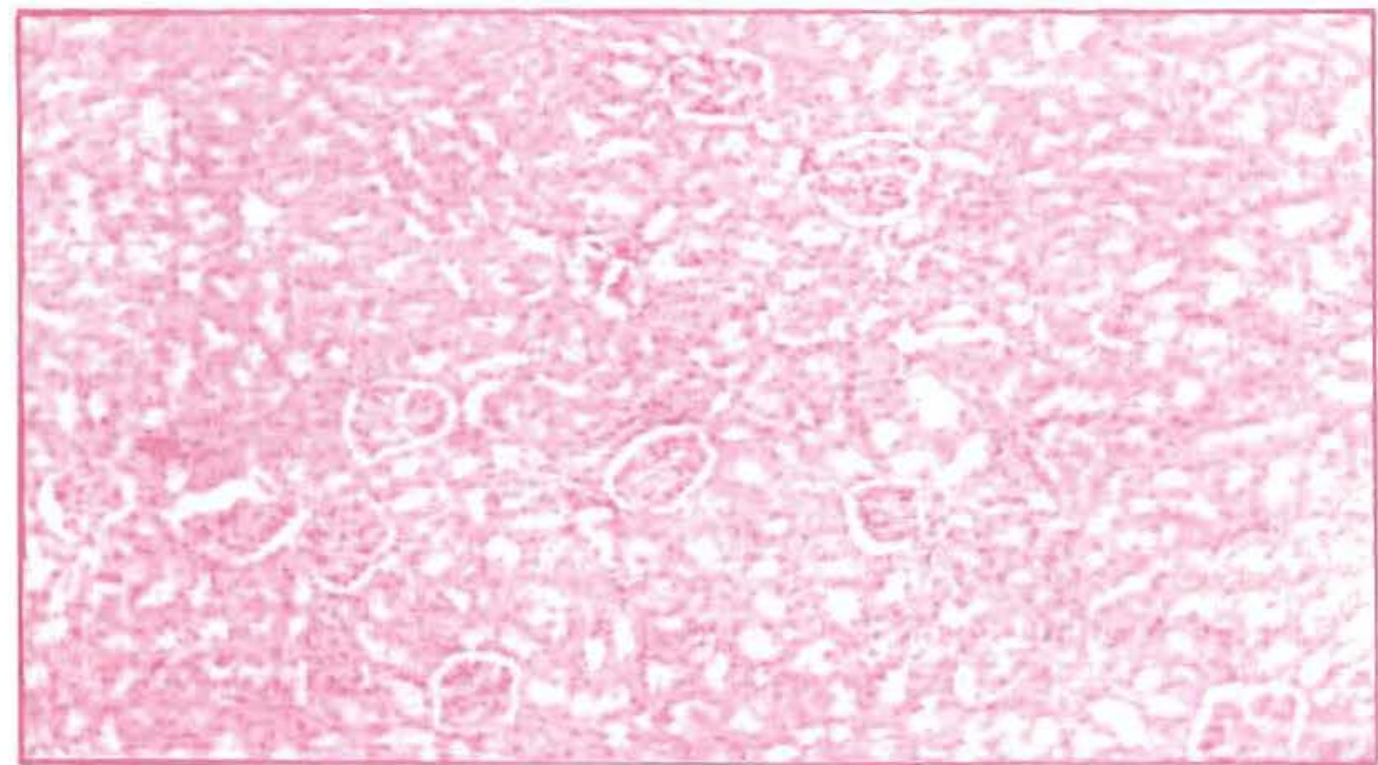

Fig. (7) : Section in kidney of rats fed repeatedly heated cottonseed oil. It shows cloudy swelling with interstitial lymphocytic infiltrate: ( $\mathrm{H} \times \&$ E x 100). 
Ali.et al ...

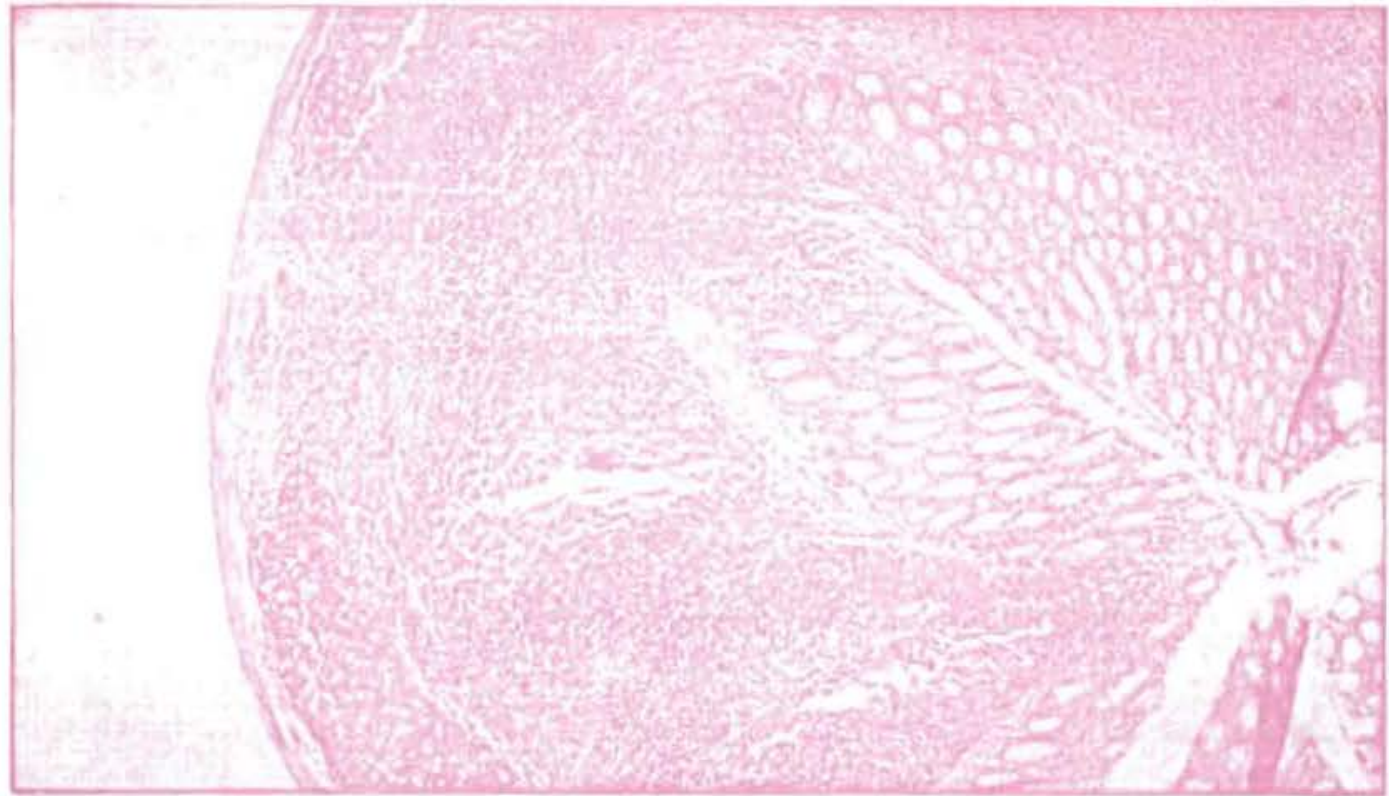

Fig. (8) ${ }^{4}$ : Section in colon of ratsi fed repeatedly heated cottonseed oil. It shows follicular colitis. (Hx \& E x 100).

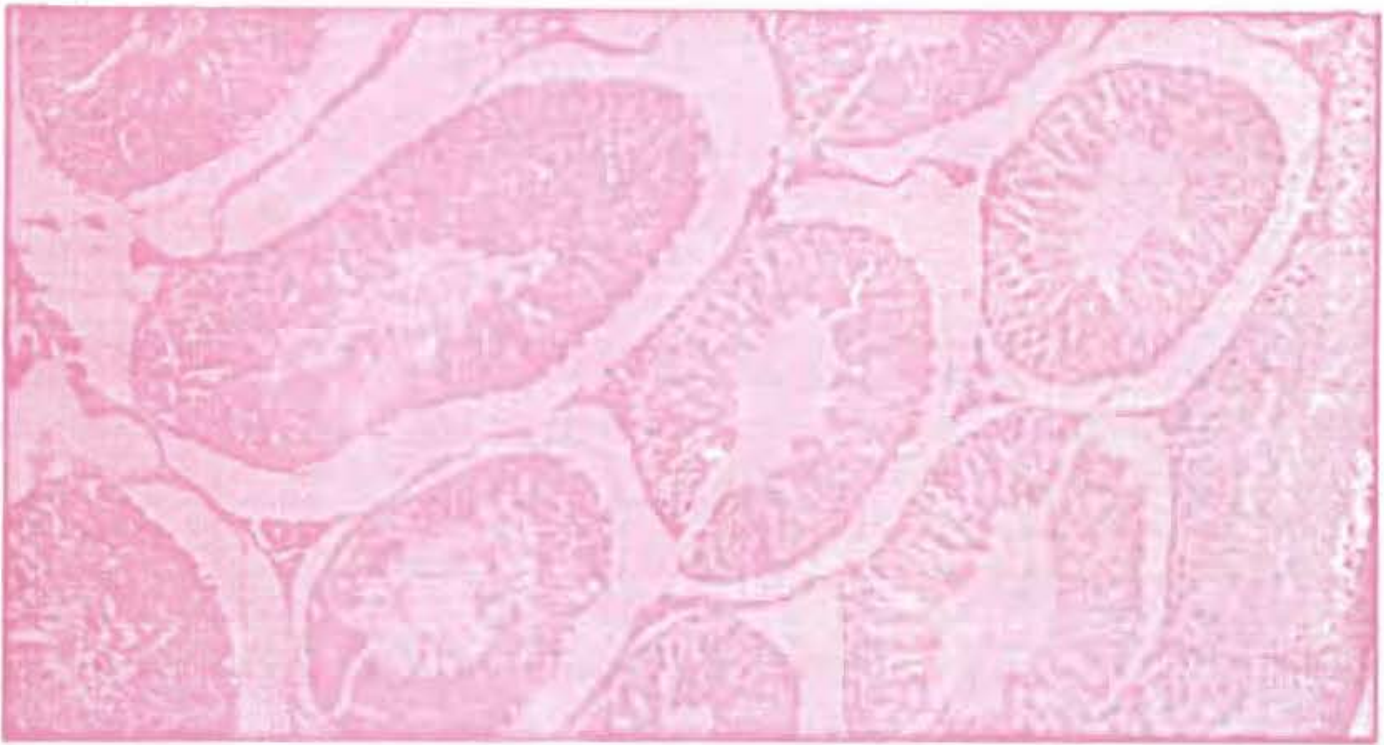

Fig. (9yosesection in testis of rats fed repeatedly heated cottonseed oil. It shows hyposper(f)atogenesis with spermatid debris inside the lumina. (Hx \& E x100). 


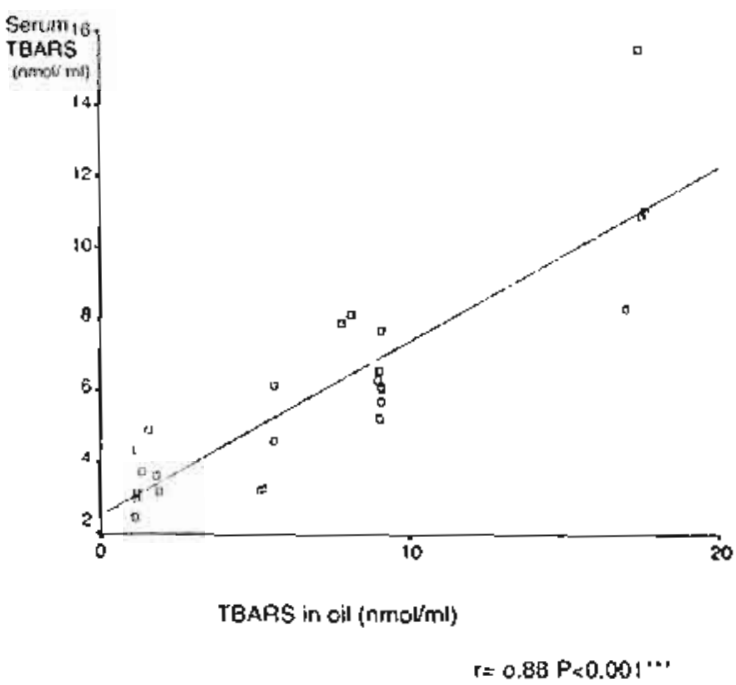

Fig. (10) : The statistical correlation between the oil content of TBARS and serum concentrations of TBARS.

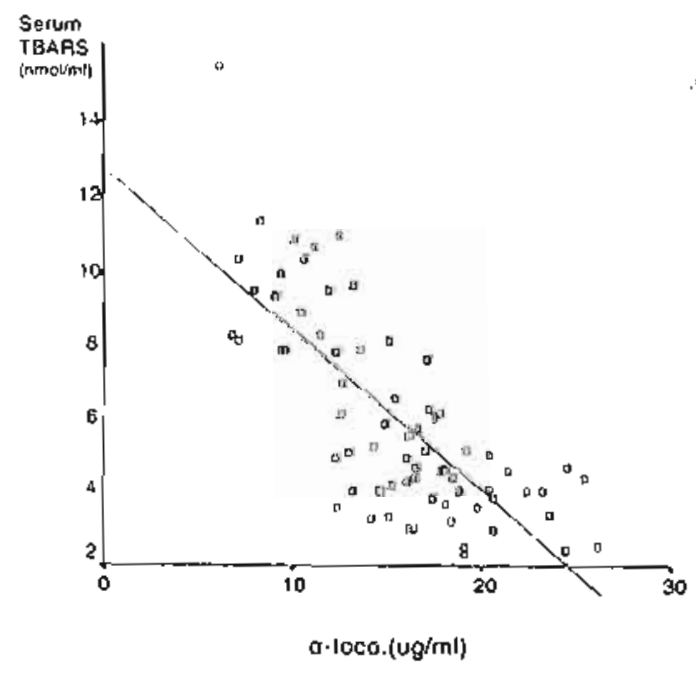

Fig. (12) : The statistical correlation between serum concentrations of TBARS and $\alpha$-tocopherol.

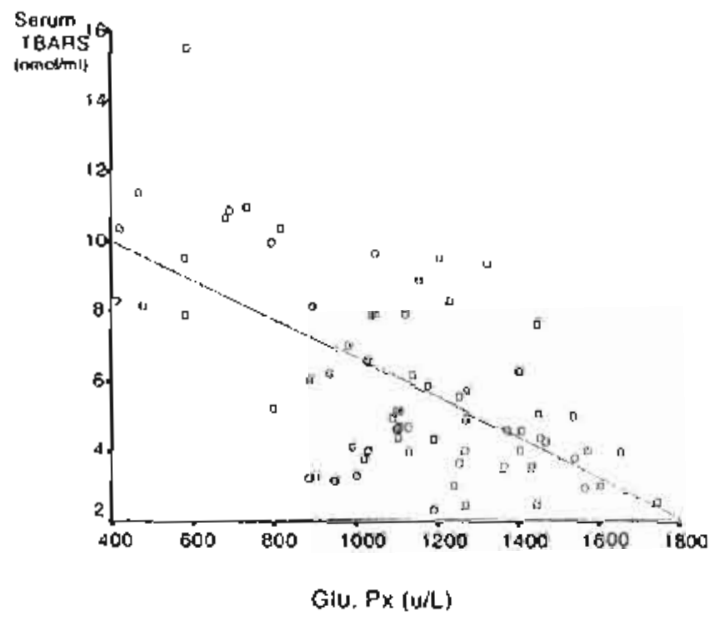

$r=-0,639 \quad F<0.001$

Fig. (11): The statistical conelation between serum concentrations of TBARS and glutathione peroxidase.

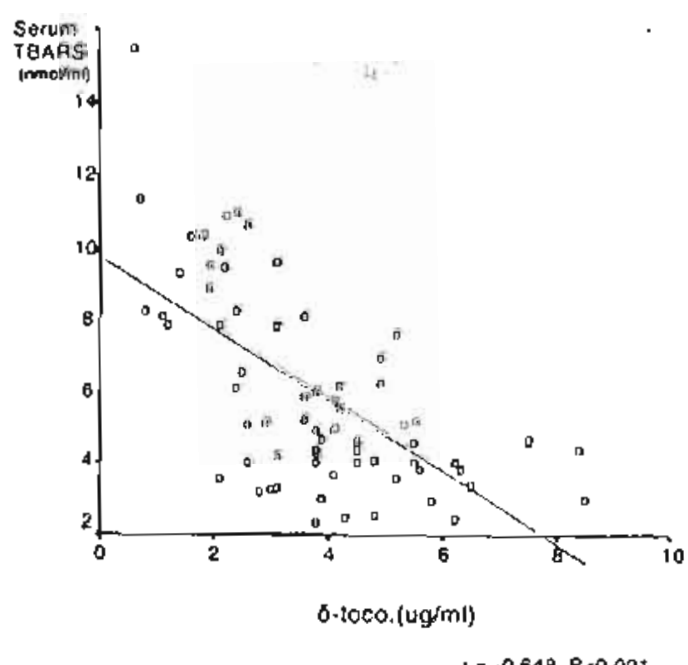

Fig. (13) : The statistical correlation between serum concentrations of TBARS and $\delta$ - tocopherol. 


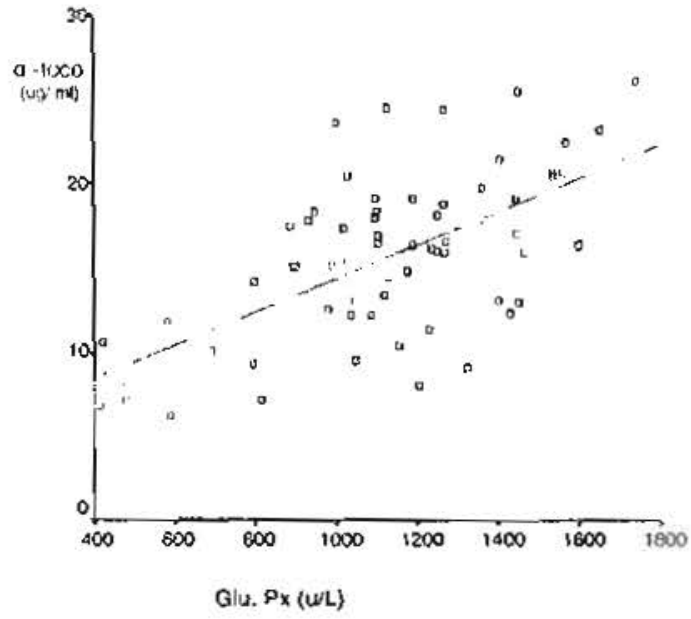

$r=0.642$ 200.cot

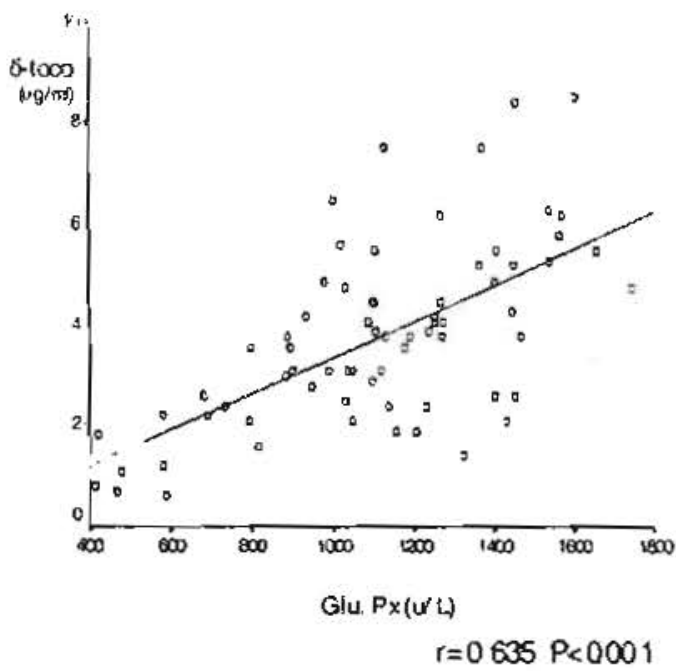

Fig. (14) : The statistical correlation between serum concentrations of glutathione peroxidase and $\alpha$-tocopherol.

Fig. (15) : The statistical correlation between serum concentrations of glutathione peroxidase and $\delta$ - tocopherol. 


\section{REFERENCES}

Abdel Khalex, S. M. and Abdel Rahman, M. K. (1996) : "Natural vitamins as antioxidants". I. Egypt Ger. Soc. Zool., 19 (A): $55-68$.

Alexander, J. C. (1981) : "Chemical and biological properties related to toxicity of heated fats". J. Toxicol. Env. Health, 7: 125 $-138$

Alexander, J. C. (1987) : "Biological observations from feeding heated corn oil and heated peanut oil in rats". J. Toxicol. Env. Health, 21: 295 - 309.

Andrikopoulos, N. K.; Dedoussis, G. V.; Falirea, A.; Kalogeropoulos, N.; and Hatzinikola, H. S. (2002): "Deterioration of ratural antioxidant species of vegetable edible oils during the domestic deep frying and pan frying of potatoes". Int. J. Food Sci. Nutr., 53 (4): 351 - 363.

Botha, I.; Przybylski, R.; and Eskin, N. A, M. (2003) : "Effect of cultivar and location on fatty acids and tocopherols in regular and genetically modified soybean oils". 94th AOCS annual meeting and expo., May 4 - 7, 2003, Kansas city, Missouri, USA.

Bruce, W. R. (1987) : "Recent hypotheses for the origin of colon cancer". Cancer Research, 47: 4237 - 4242.
Burk, R. F.; Hill, K. E.; Awad, J. A.; Morrow, J. D. and Lyons, P. R. (1995) : "Liver and kidney necrosis in selenium deficient rats depleted glutathione". Lab. Invest., $72(6): 723-730$.

Cheng, W. H.; Ho, Y. S.; Valantine, B. A.; Ross, D. A.; Combs, G. F. and Lei, X: G. (1998): "Cellular glutathione peroxidase is the mediator of body selenium to protect against paraquat lethality in transgenic mice". J. Nutr., 128: 1070 - 1076.

Doumas, B. To; Watson, W. A. and Biggs, H. G. (1971) : "Albumin standards and the measurement of serum albumin bromcresol green". Clin. Chim. Acta, 31: 87 - 96 .

Draper, H. $\mathrm{H}_{3}$; Squires, E. J.; Mahmoodi, H.; Wu, J ; Agarwal, S. and Hadley, M. A. (1993) : "Competitive evaluation of thiobarbituric acid methods for the determination of malonaldehydes in biological materials". Free Rad. Biol. Med., 15: 353 363.

Eder, K. and Stangl, G. (2000) : "Plasma thyroxin and cholesterol concentrations of miniature pigs are influenced by thermally. oxidized dietary lipids". J. Nutr., 130: $116-121$.

El-Mehallawi, I.; Awara, W. M.; Moustafa, K. A. and Ibrahim, W. M. (2000) : "Peroxidative damage and cancer colon 
risk in animals fed repeatedly heated cottonseed oil". Mans. J. Forensic Med. Clin. Toxicol., 8 (2): 191 - 212.

F. A. O. (1994) : "Fats and oils in human nutrition". Report of a joint expert consultation organized by the Food and Agriculture Organization of the United Nations and the World Health Organization, 19 26 October, Rome, Italy.

Fox, B. A. and Cameron, A. G. (1995) : Food Science, Nutrition, and Health. 6th ed., Hodder Headline group publishing, Chapters 5, 6 and 15, P.P. 45 - 69, $70-94$ and $279-297$.

Gutbrie, H. A.; Picciano, M. F. and Scott, A. (1995) : Human Nutrition. Mosby, Chapte:s 4 and 11, P.P. $111-148$ and $393-434$.

Heinegard, D. and Tiderstrom, K. (1973) : "Determination of serum creatinine by a direct colorimetric method". Clin. Chim. Acta, 43: $305-310$.

Liu, J. F. and Huang, C. J. (1995) : " Tissue tocopherol retention in male rats is compromised by feeding diets containing oxidized frying oil". J. Nutr., 125: 3071 3080.

Liu, J. F.; Lee, Y. W.; and Chang, F. C. (2000) : " Effects of oxidized frying oil and dietary vitamin $\mathrm{C}$ levels on the antioxidant status of guinea pigs". N. Taipei J. Med., 2: $93-99$.

Maraschiello, C.; Sarraga, C. and Garcia Regueiro, J. A. (1999) : "Glutathione peroxidase activity, thiobarbituric acid and $\alpha$-tocopherol in meat from chickens fed different diets". J. Agric. Food Chem., 47 (3): 867 - 872.

Narasimhamurthy, K. and Raina, P. L. (1999) : "Longterm feeding effects of thermally oxidized oils on antioxidant enzymes in rats". Indian J. Exp. Biol., 37 (10): 1042 - 1045.

Neilsen, H. K.; Finot, P. A. and Hurell, R. F. (1985) : "Reactions of proteins with oxidizing lipids. 2. Influence on protein quality and on the bioavailability of lysine, methionine, cystiene and tryptophan as measured in rat assays". Br. J. Nutr., 53: $75-86$.

Nwanguma, B. C.; Acheba, A. C.; Ezeanyika, I. U. and Eze, I. C. (1999) : "Toxicity of oxidized fats. II: Tissue levels of lipid peroxides in rats fed a thermally oxidized corn oil diet". Food Chem. Toxicol., 37 (4): 413 - 416.

Paglia, D. E. and Valentine, J. P. (1967) : "Studies in the quantitative characterization of erythrocyte glutathione peroxidase". J. Lab. Clin. Med., 70: 158 - 169. 
Reitman, S. and Frankel, S. (1957) : "Colorimetric method for determination of serum glutamate oxaloacetic and glutamate pyruvic transaminases". Am. J. Clin. Path., 28: 58 - 61.

Saguy, I. S. and Dara, D. (2003) : "Integrated approach to deep fat frying: engineering, nutrition, health and consumer aspects". J. Food Eng., 56: 143 - 153.

Sampson, E. J.; Baird, M. A. and Burtis, C. A. (1980) : "A coupled enzyme equilibrium method for measuring urea in serum". Clin. Chem., 26: 816-826.

Scaccini, C,; Nardini, Mø; D'Aquino, $M_{i ;}$ Gentili, V.; Di Felice, M. and Tomassi, G. (1992) : "Effect of dietary oils on lipid peroxidation and on antioxidant parameters of rat plasma and lipoprotein fractions". J. Lipid Res., 33: 627 - 633.

Sheehy, P. I. A.; Morrissey, P. A. and Flynn, A. (1994) : "Consumption of thermally oxidized sunflower oil by chicks reduces $\alpha$-tocopherol status and íncreases susceptibility of tissues to lipid oxidation". Br. J.Nutr., 71: 53 - 65.

Stevens, A. (1982) : The haematoxylins.In : Theory and Practice of Histological Techniques. Bancroft, J.D. and Stevens, A.(Eds.), Churchill Livingstone, 2nd ed., Ch.7, P.P. 109-121.

Tewfik, I. H.; Ismail, H. M. and Sumar, S. (1998) : "The effect of intermittent heating on some chemical parameters in refined oils used in Egypt. A public health nutrition concern". Int. J. Food Sci. Nutr., 49 (5): 339-342.

Warner, K. (1999) : " Impact of high temperature food processing on fats and oils". Adv. Exp. Med. Biol., 459: 6777.

Zalata, A. A.; Christophe, A. B.; Depuydt, C. E.; Schoonjans, F. and Comhaire, F. H. (1998) : "The fatty acid composition of plasma lipoprotein of spermatozoa from infertile patients". Mol. Human Rep., 4 (2): 111 - 118. 


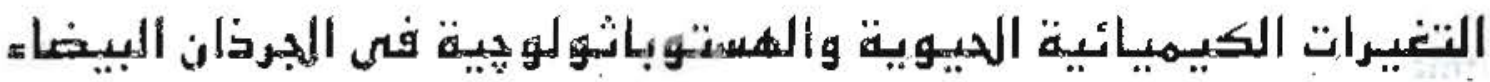

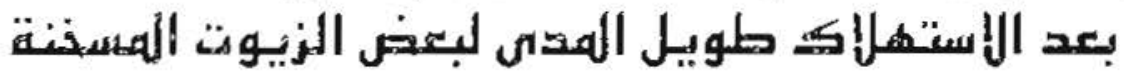

\author{
الشتركمن فى البهث

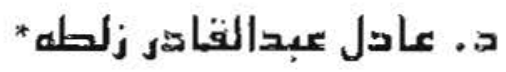

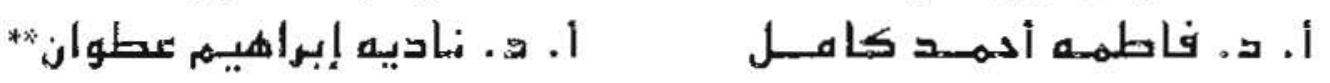

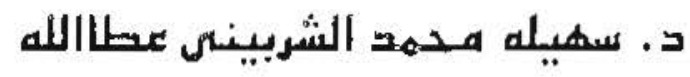

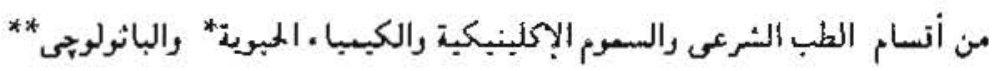 \\ كلبة ألطب - جامعة المنصرة
}

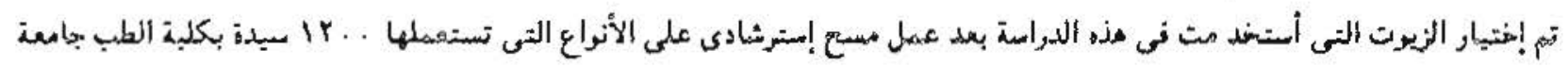

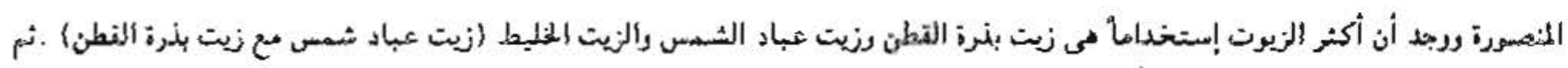

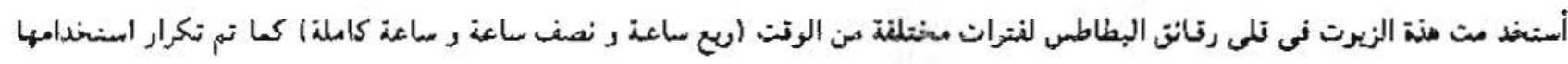

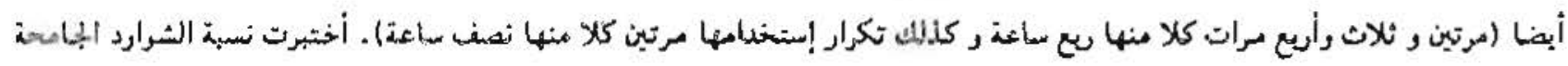

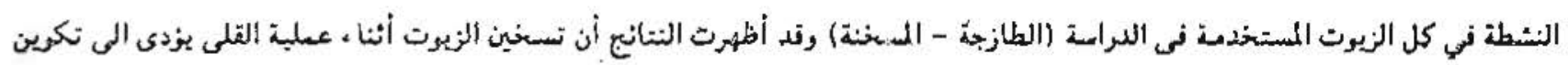

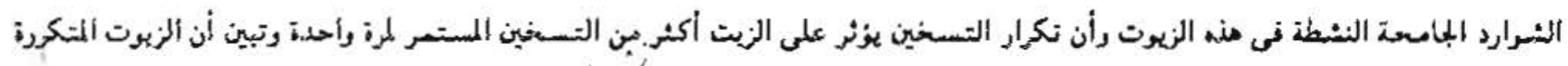

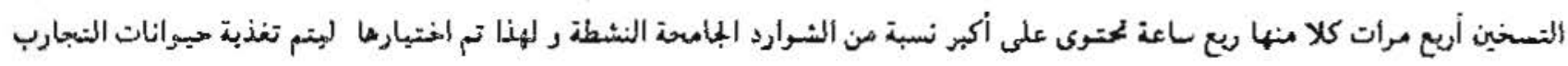

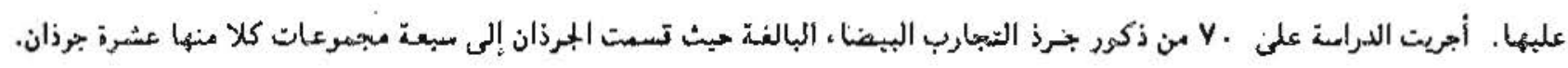

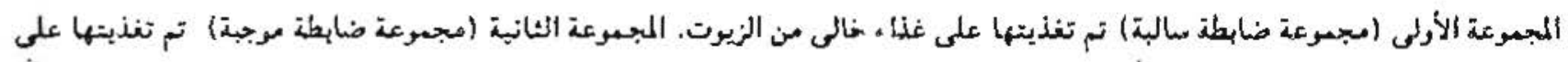

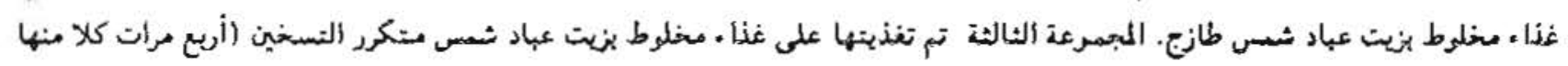

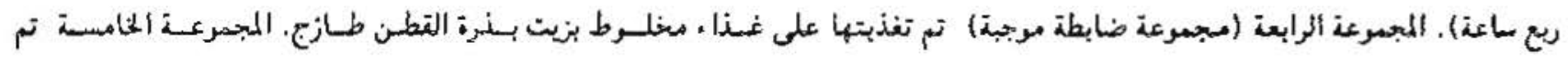

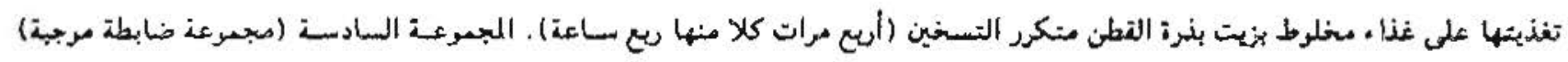

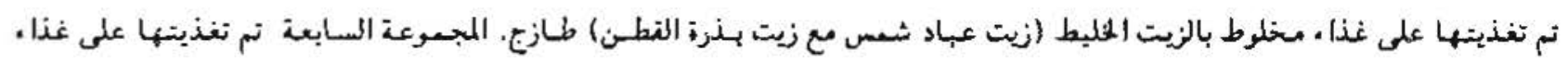

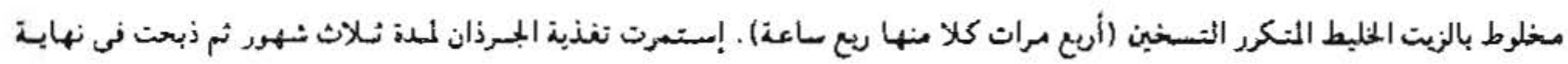

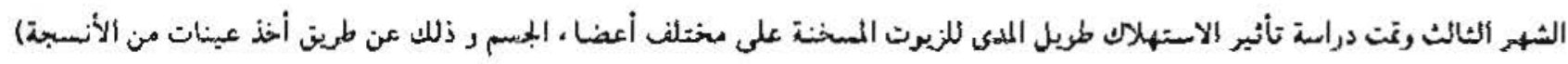

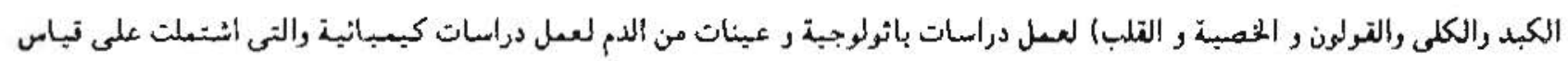




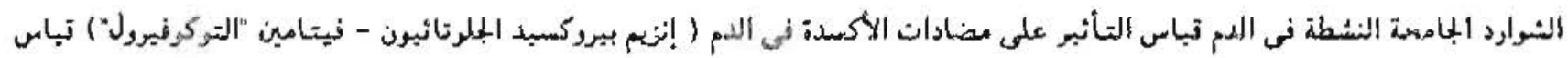
التأثبر على وظانف الكيد ( إنزيعات الكبد - الألبومبن) رالكلى (البكرياتبنيجن - البوريا) ... أظهرت النتانج أن الإستعمال طريل المدى للزيبرت

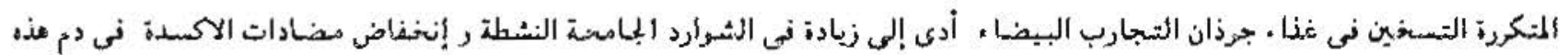

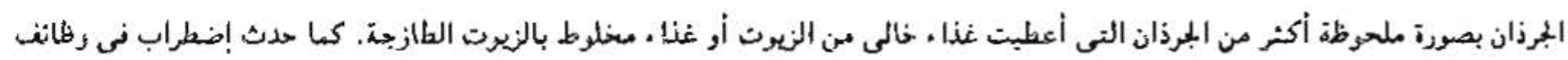

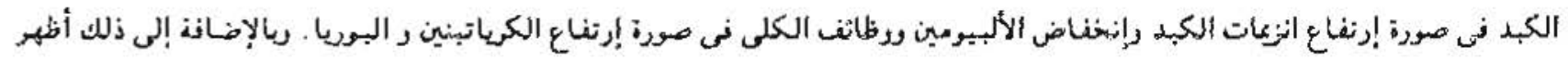

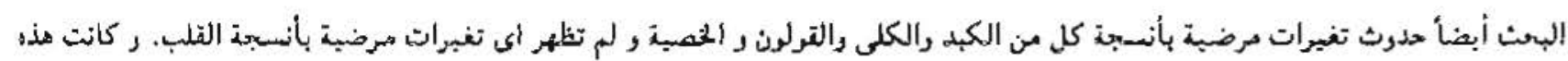

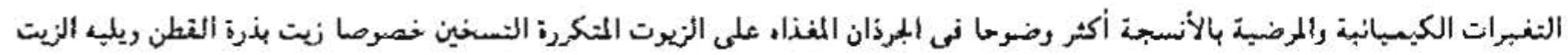
الحلبط تم زيت عباد ألشـس.

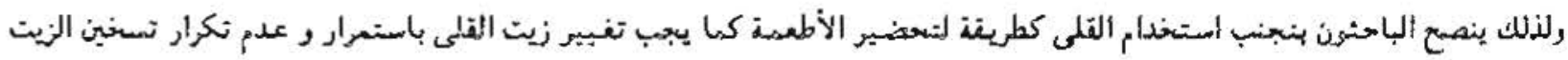

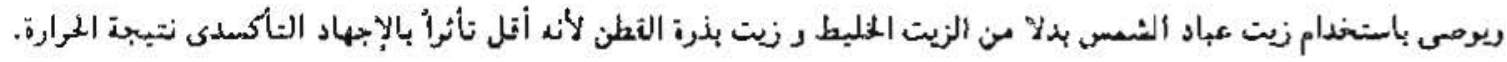




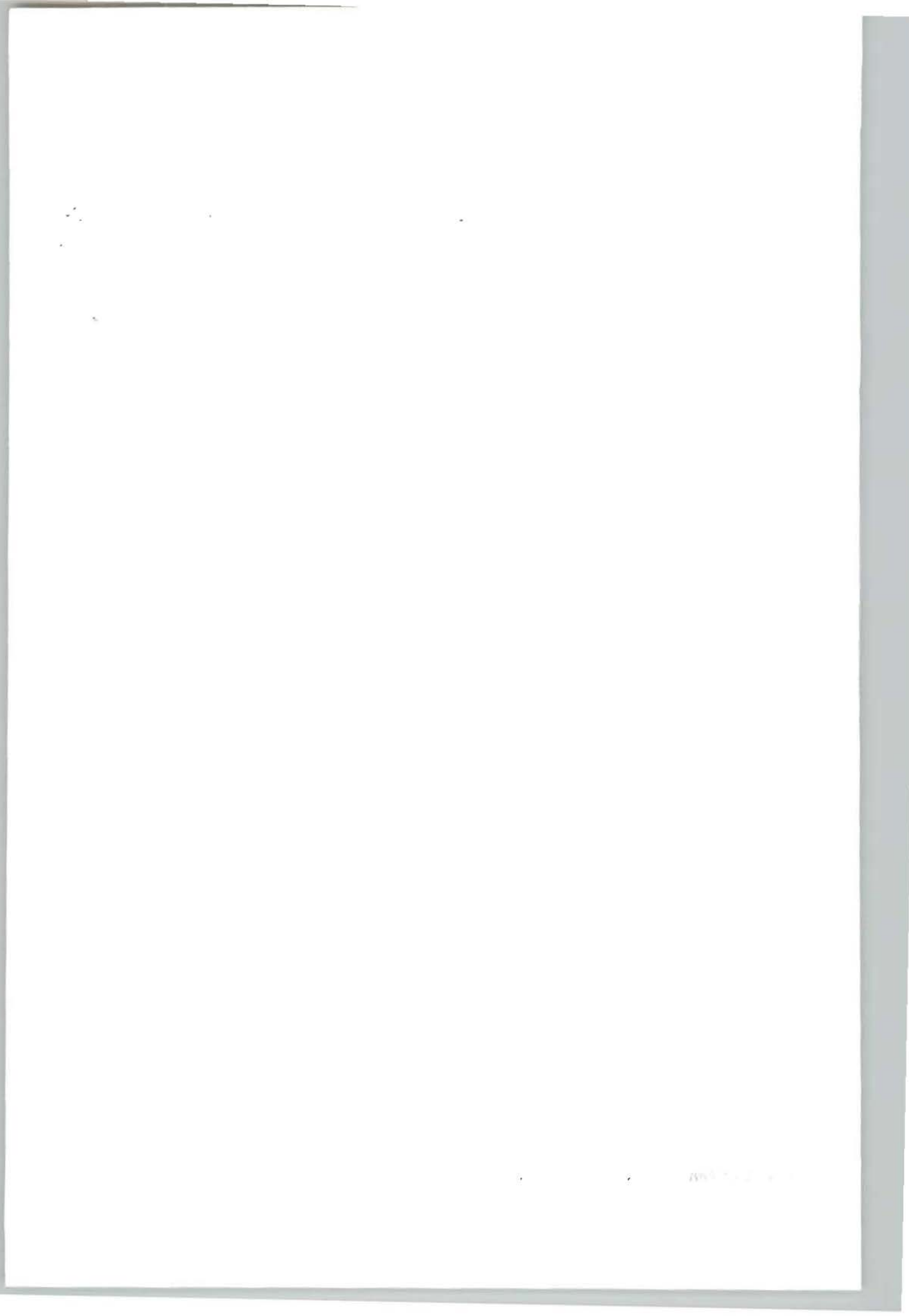

